\title{
Seasonality of occurrence of deep vein thrombosis of the lower limbs
}

\author{
Malgorzata Dybowska', Witold Z. Tomkowski', Pawel Kuca', Dariusz Chmielewski \\ 'Cardio-Pulmonary Intensive Care Department, National Institute of Tuberculosis and Lung Diseases, Warsaw, Poland \\ ${ }^{2}$ Department of Orthopedic Surgery and Traumatology, HOSPITEN Hospital, Puerto del Carmen - Lanzarote, Spain
}

No conflict of interest

\begin{abstract}
Published data concerning increased incidence of venous thromboembolic disease (VTE) in different seasons of the year are divergent.

In the 12-month period lasting from $1^{\text {st }}$ December 2007 to 30 $0^{\text {th }}$ November 2008, 48 cases of deep vein thrombosis (DVT) of the lower limbs were diagnosed in the population of Bemowo, a district of Warsaw. The analysis of the incidence of DVT of the lower limbs occurrence at particular times of the year was performed. During the winter time, II episodes of DVT were diagnosed and, respectively, 16 episodes during the spring, II during the summer and 10 episodes of DVT during autumn.

Using the Chi-square test, the authors revealed no statistically significant differences in the incidence of DVT of the lower extremities in different seasons.
\end{abstract}

Key words: venous thromboembolism, deep vein thrombosis, epidemiology

Acta Angiol 2015; $21,1: 8-10$

\section{Introduction}

Data on epidemiology of increased incidence of venous thromboembolic disease (VTE) at particular times of the year are divergent.

There are both reports of increased incidence of VTE in the winter months [1-7] and studies in which there was no seasonal incidence of deep vein thrombosis (DVT) [8-10] in current literature.

\section{Methodology}

In this study, we analyzed the incidence of deep vein thrombosis in the population of the 104,262 inhabitants of Bemowo during 12 months (from I ${ }^{\text {st }}$ December
2007 to $30^{\text {th }}$ November 2008). This period was divided into three-month intervals corresponding to different seasons of the year.

We adopted the following criteria:

- Winter: from December I to February 28;

- Spring: from March I to May 31;

- Summer: from June I to August 31;

- Autumn: from September I to November 30.

Demographic characteristics of population are shown in Table I.

40 general practitioner (GP) practices cooperated in this period with the center performing ultrasound tests. The only inclusion criterion in the study was: patients with clinical signs of deep vein thrombosis of the lower limbs living in Bemowo district. 
Table I. Demographic characteristics of population

\begin{tabular}{|l|l|}
\hline Number of people & Population \\
\hline Age 20-40 years & 104262 \\
\hline Age 4I-60 years & $44 \%$ \\
\hline Age 6I-80 years & $36 \%$ \\
\hline Age $>80$ years & $17 \%$ \\
\hline Male & $3 \%$ \\
\hline Female & $47 \%$ \\
\hline
\end{tabular}

In order to confirm thrombosis, all patients with symptoms of deep vein thrombosis of the lower extremities underwent ultrasonography of deep veins. We analyzed both proximal and distal portion of deep venous system of the lower limbs. DVT was proved by an ultrasound compression test performed in accordance with generally accepted principles [1 I-13].

The study was performed using Vivid 3 S/N 6452 General Electric Medical Systems.

The study was approved by local ethical committee (EC at the Institute of TB and Lung Diseases in Warsaw, Poland).

All patients gave written consent for ultrasonography examination.

\section{Statistical analysis}

The statistical significance of these correlations was tested using the Chi-square test.

\section{Results}

During the 12-month period from I ${ }^{\text {st }}$ December 2007 to $30^{\text {th }}$ November 2008, 48 cases of DVT of the lower limbs were diagnosed in the population of Bemowo.

The analysis of lower limbs DVT morbidity at particular times of the year was performed.

In winter we found II episodes of DVT and in other seasons of the year, respectively, 16 in the spring, II in the summer and 10 episodes in the autumn.

Using the Chi-square test, we revealed no statistically significant difference $(p=0.6077)$ in the incidence of DVT of the lower limbs at particular times of the year.

The summary of the results is presented in Table 2 .

\section{Summary}

In a one-year observation, in the studied population, there was no statistically significant correlation between the season of the year and the occurrence of confirmed deep vein thrombosis of the lower limbs. A limitation of the presented results is the small number of confirmed DVT (48 identified cases of lower limbs DVT).
Table 2. Comparison of the incidence of lower limb DVT in different seasons of the year in the population of Bemowo during 12 -month period

\begin{tabular}{|l|l|l|}
\hline Season & N & IVT \\
& $\mathrm{N} / 100000$ & 10.55 \\
\hline Spring & $\mathrm{N}$ & 16 \\
& $\mathrm{~N} / 100000$ & 15.35 \\
\hline Summer & $\mathrm{N}$ & $\mathrm{II}$ \\
& $\mathrm{N} / 100000$ & 10.55 \\
\hline Autumn & $\mathrm{N}$ & 10 \\
& $\mathrm{~N} / 100000$ & 9.59 \\
\hline & & $\mathrm{P}=0.6077$ \\
\hline
\end{tabular}

\section{Discussion}

Epidemiological data regarding the increased incidence of venous thromboembolic disease (VTE) in particular seasons of the year are divergent. In a retrospective work and in other publications, Bounameaux and colleagues found no seasonal incidence of DVT [8-10].

However, in the literature there are reports of increased incidence of VTE in the winter months [I-7]. Increased incidence of DVT in the winter is being explained by some authors by changes in the coagulation system associated with the low temperature, which raises the tendency of thrombus formation, reduced venous flow in the legs as well as a vasoconstrictor effect of low temperatures on veins [5, 14].

French data confirms the greater number of hospitalizations due to VTE in the winter months [5]. The authors suggest that hypercoagulability in the winter is probably associated with more frequent respiratory infections. In addition, during the winter an important reduction of physical activity usually occurs, and the relative immobilization is a recognized risk factor of VTE [5].

In a one-year observation, in the present study, there was no statistically significant correlation between the seasons of the year and the frequency of confirmed deep vein thrombosis of the lower limbs. However, the limitation of the presented results is a low incidence of confirmed DVT.

\section{References}

I. Andreou ER, Koru-Sengul T, Linkins L, Bates SM, Ginsberg JS, Kearon C (2008) Differences in clinical presentation of deep vein thrombosis in men and women. J Thromb Haemost; 6: $17|3-17| 9$.

2. Wroblewski BM, Siney P, White R (1990) Seasonal variation in fatal pulmonary embolism after hip arthroplasty. Lancet; 335: 56. 
3. Gallerani M, Boari B, de Toma D, Salmi R, Manfredini R (2004) Seasonal variation in the occurrence of deep vein thrombosis. Med Sci Monit; I0: CRI9I-196.

4. Fink AM, Mayer W, Steiner A (2002) Seasonal variations of deep vein thrombosis and its influence on the location of the thrombus. Thromb Res; 106: 97-100.

5. Boulay F, Berthier F, Schoukroun G, Raybaut C, Gendreike Y, Blaive B (200I) Seasonal variations in hospital admission for deep vein thrombosis and pulmonary embolism: analysis of discharge data. BMJ; 323: 60I-602.

6. Dentali F, Ageno W, Rencan E et al (20I I) Seasonal and monthly variability in the incidence of venous thromboembolism. A systemic review and a meta-analysis of the literature. Thromb Haemost; 106: 439-447.

7. Ribeiro DD, Lijfering WM, Rosendaal FR (20/3) Seasonal variation of venous thrombosis: a consecutive case series within studies from Leiden, Milan and Tromsø: reply to a rebuttal. J Thromb Haemost; I I: 570-572.

8. Stein PD, Kayali F, Olson RE (2004) Analysis of occurrence of venous thromboembolic disease in the four seasons. Am J Cardiol; 93: $5|I-5| 3$.
9. Yusuf HR, Reyes N, Zhang QC et al (2014) Hospitalizations of adults $\geq 60$ years of age with venous thromboembolism. Clin Appl Thromb Hemost; 20: 136-142.

10. Bounameaux H, Hicklin L, Desmarais S (1996) Seasonal variation in deep vein thrombosis. BMJ; 31 2: 284-285.

II. Lensing AW, Doris Cl, McGrath FP et al (1997) A comparison of compression ultrasound with color Doppler ultrasound for the diagnosis of symptomless postoperative deep vein thrombosis. Arch Intern Med; I57: 765-768.

12. Fraisse F, Holzapfel L, Couland JM et al (2000) Nadroparin in the prevention of deep vein thrombosis in acute decompensated COPD. The Association of Non-University Affiliated Intensive Care Specialist Physician of France. Am J Respir Crit Care Med; |61: |109-II|4.

13. Małek G, Hajduk B, Tomkowski W, Skórski M (2003) Ultrasonograficzne badanie żył kończyn dolnych i żyły głównej dolnej. In: Małek G (ed.) Ultrasonografia dopplerowska. Zastosowanie kliniczne. Warszawa: Medipage; 2003: 38-54.

14. McNally M, Mollan RAB (1993) Total hip replacement, lower limb blood flow and venous thrombogenesis. J Bone Joint Surg; 75: 640-644. 